\title{
HAD-HAD PERUBAHAN BOLEH DITERIMA DALAM PELANCONGAN : SATU TINJAUAN TEORI DAN KONSEPTUAL
}

\section{LIMIT OF ACCEPTABLE CHANGE IN TOURISM: A REVIEW OF THEORY AND CONCEPTUAL}

\author{
Mohamad Pirdaus bin Yusoh ${ }^{1,}$ Jabil Mapjabil $^{2}$, Nurhazliyana Hanafi ${ }^{1}$ \\ ${ }^{1}$ Universiti Malaysia Terengganu (UMT), Terengganu \\ ${ }^{2}$ Universiti Malaysia Sabah, (UMS), Sabah
}

Correspondence: Mohamad Pirdaus Yusoh (m.pirdaus@umt.edu.my)

\begin{abstract}
Limits of Acceptable Change (LAC) in tourism is a method in determining the level of change that can be accommodated in a tourist destination. In January 1985, the LAC was issued by the Forest Service and was first implemented on April 1, 1987 on the Bob Marshall wilderness complex. Initially, it was designed to be applied in the United States wilderness system for better management following increased demand and impact from climbers and backpackers. This process assesses the impact that occurs during the activity, measures the changes that will be received, monitors what is happening systematically and determines the appropriate action and agreed by several stakeholders after discussion. LAC differs from caryying capacity because the concept of carrying capacity itself only focuses on biophysical perspectives while LAC is more encouraging discussion, raising opinions and suggestions from the public and management. It is considered the best system in resolving an issue at a tourist location. Thus, this paper will examine the concepts and steps in resolving issues based on this LAC system.
\end{abstract}

Keyword: Limit Of Acceptable Change (LAC), Theory, Conceptual, Tourism

\begin{abstract}
ABSTRAK
Had perubahan boleh diterima (Limits of acceptable change - LAC) dalam pelancongan adalah satu metod dalam menentukan tahap perubahan yang mampu ditampung di sesebuah destinasi pelancongan. Pada Januari 1985, LAC diterbitkan oleh Forest Service dan dilaksanakan buat kali pertama pada 1 April 1987 terhadap kompleks hutan belantara Bob Marshall. Pada mulanya, konsep ini direka untuk diaplikasikan dalam sistem hutan belantara Amerika Syarikat bagi pengurusan yang lebih baik berikutan peningkatan permintaan serta kesan daripada pendaki dan backpacker. Proses ini menilai kesan yang berlaku semasa aktiviti, mengukur perubahan yang akan diterima, memantau apa yang berlaku secara sistematik dan teratur dan menentukan tindakan yang sesuai dan dipersetujui oleh beberapa pihak berkepentingan selepas perbincangan. LAC berbeza dengan kapasiti daya tampung (caryying capacity) kerana konsep kapasiti daya tampung itu sendiri hanya memfokuskan kepada perspektif biofizikal manakala LAC lebih menggalakkan perbincangan,
\end{abstract}


menimbulkan pendapat dan cadangan daripada orang awam dan pihak pengurusan. Ia dianggap sistem yang terbaik dalam menyelesaikan sesuatu isu di lokasi pelancongan. Justeru, artikel ini akan meneliti konsep dan langkah-langkah dalam menyelesaikan isu berdasarkan sistem LAC ini.

Kata kunci : Had Perubahan Boleh Diterima (LAC), Teori, Konseptual, Pelancongan

\section{Pengenalan}

Pelancongan merupakan satu sektor perkhidmatan yang pesat membangun dan penyumbang hasil pendapatan kepada kebanyakan negara di dunia. Dalam konteks Malaysia, kerajaan memperuntukkan sebanyak RM316 juta untuk bajet tahun 2015 dalam pembangunan sektor pelancongan. Jumlah ketibaan pelancong ke Malaysia meningkat dari 25.7 juta orang pada tahun 2013 kepada 27.4 juta orang pada tahun 2014 dengan nilai pendapatan mencecah RM72 bilion (Tourism Malaysia, 2015). Sejajar dengan kepesatan pembangunan pelancongan di negara ini, isu alam sekitar perlu diambil perhatian yang serius agar kelestariannya terus kekal terpelihara. Salah satu pendekatan awal dalam pemuliharaan ini adalah wujudnya konsep kapasiti daya tampung (carrying capacity). Konsep ini di buat bagi memudahkan aspek pengurusan dalam sesebuah sektor contohnya seperti sektor pelancongan. Namun setelah dikaji oleh beberapa penyelidik, mereka mendapati sistem ini mempunyai kelemahan dan keputusannya mempunyai ralat dan tidak tepat.

Pelbagai pendekatan atau metodologi yang telah dijalankan dalam memulihara kawasan pelancongan daripada kemusnahan dan kerosakan. Satu metodologi baru diwujudkan bagi mengatasi masalah ini. Sistem tersebut digelar Had Perubahan Boleh Diterima (LAC) (Limits of Acceptable Change, LAC). LAC merupakan rumusan daripada konsep kapasiti daya tampung (carrying capacity) yang menaksir atau menilai 'berapa banyak perubahan yang boleh diterima' dalam pembangunan di sesuatu kawasan dengan menentukan penunjuk persekitaran terpilih untuk merumuskan julat yang boleh diterima manusia berasaskan kepada alam sekitar yang digunakan dan kehendak sosial dan ia turut memberikan cadangan untuk memulakan tindakan bagi mengawal limpahan perubahan tersebut (Stankey et al., 1985 dalam Aw, 2013).

\section{Sorotan Literatur}

\section{Konsep had perubahan boleh diterima (Limits of acceptable change - LAC)}

LAC adalah satu proses atau metodologi yang dikemukakan oleh Stankey et al. (1985) dan mula dilaksanakan pada tahun 1987. Kerangka proses perancangan atau metodologi ini di buat bagi meningkatkan pengurusan rekreasi di kawasan yang dilindungi (Cole \& McCool, 1997). Ia dijalankan buat kali pertama pada 1 April 1987 terhadap kompleks hutan belantara Bob Marshall. Pada mulanya, ia direka untuk diaplikasikan dalam sistem hutan belantara Amerika Syarikat (USA) bagi pengurusan yang lebih baik berikutan peningkatan permintaan serta kesan daripada pendaki dan backpacker. Ia juga dibangunkan bagi memberi sokongan kepada pengurusan rekreasi yang mampan bagi kegunaan kawasan hutan yang dilindungi di USA. Berbanding dengan memberi tumpuan secara langsung terhadap jumlah pengunjung, proses ini memerlukan definisi penerimaan 
sosial dan keadaan alam sekitar dalam kawasan pengurusan serta langkah-langkah yang telah ditetapkan bagi memantau dan melindunginya (Frissel, 1963; Cole \& Stankey, 1998; Stankey et al.,1985). Pada dasarnya, LAC direka bagi mencapai keseimbangan yang mampan antara alam sekitar dan keperluan sosial.

Sebenarnya proses ini direka untuk menunjukkan kegagalan pendekatan "kapasiti daya tampung" (carrying capacity) dalam kegunaan pengurusan pengunjung. Konsep LAC digunakan secara meluas dalam bidang kajian hutan rimba (Roggenbuck et al., 1993) perancangan dan pembangunan pelancongan (Ahn et al., 2002) penilaian kesan alam sekitar untuk aktiviti pengorekan di Great Barrier Reef Marine Park (Oliver, 1995) dan memantau perubahan dalam populasi biologi organisma bukan tidak aktif (Marsh, 1995). Ia juga telah diadaptasikan ke dalam bidang pelancongan (McCool, 1994) dan telah digunakan dalam beberapa situasi yang melibatkan alam sekitar. Soalan asas yang diberi tumpuan oleh LAC adalah "Apakah keadaan yang sesuai dan yang boleh diterima di sesuatu kawasan?" telah dihujahkan untuk digunakan di tapak warisan budaya (McCool, 2006).

LAC ini adalah seperti rangka kerja yang lain yang digunakan dalam proses perancangan yang merangkumi skop yang lebih luas berkaitan pembuat keputusan di kawasan dilindungi serta boleh dijadikan kerangka kerja untuk membantu keputusan yang khusus untuk pengunjung dan pengurusan pelancongan. Dengan adanya ukuran dan indikator, ia berkesan terhadap proses penciptaan bagi menilai keberkesanan pengurusan. Pelbagai gambaran berkaitan proses ini antaranya pendekatan "pengurusan dengan objektif" atau pendekatan "berasaskan-indikator" terhadap pengurusan. Ia boleh dilihat sebagai kedua-dua konsep (contohnya, satu fokus kepada perbincangan mengenai kesesuaian atau penerimaan terhadap pelbagai keadaan) serta sebagai satu langkah asas kerangka kerja untuk penstrukturan pengurusan dan pemegang taruh.

Asas LAC adalah berdasarkan saranan ini:

i. Mana-mana penggunaan manusia (contoh dalam sektor pelancongan) dalam kawasan semula jadi yang menyebabkan perubahan terhadap keadaan biofizikal dan pengalaman pengunjung.

ii. Watak dan jumlah akibat perubahan sesetengah isu menjadikan ia tidak boleh diterima oleh sekurang-kurangnya sesetengah kumpulan pengundi.

iii. Wujud kepelbagaian dalam biofizikal dan sosial dan mungkin wajar.

iv. Pemeliharaan warisan dan akses (untuk lawatan) adalah matlamat yang sebahagiannya bersaing tetapi sebahagiannya bertindih.

v. Pengurusan dikehendaki untuk mengekalkan kesan yang disebabkan oleh manusia dalam satu tahap penerimaan dan kesesuaian

Dalam hal ini, LAC bertindak sebagai rangka kerja perancangan yang menggabungkan usul ini ke dalam satu siri langkah-langkah dengan urutan tertentu dan secara rasional yang mewakili satu pendekatan pengurusan yang mudah suai. 


\section{Metodologi kajian}

Artikel ini menggunakan metodologi analisis dokumen. Analisis dokumen adalah prosedur yang sistematik untuk mengkaji atau menilai dokumen, sama ada bahan cetak atau elektronik. Seperti kaedah analisis lain dalam penyelidikan kualitatif, analisis dokumen memerlukan data yang diteliti dan ditafsirkan untuk mendapatkan makna, memperoleh pemahaman dan mengembangkan pengetahuan empirik (Corbin \& Strauss, 2008). Analisis dokumen sering digunakan dengan kombinasi dalam kaedah penyelidikan kualitatif lain sebagai alat triangulasi - "gabungan metodologi dalam kajian fenomena yang sama" (Denzin, 1970). Oleh itu, dalam kajian ini, dokumen kajian terdahulu diteliti bagi memberikan gambaran serta definisi bagi konsep LAC. Antara kajian terdahulu yang diteliti adalah Stankey et al. (1985) yang memperkenalkan konsep LAC. Selain itu, Roggenbuck et al. (1993) yang menerapkan konsep LAC dalam bidang kajian hutan rimba dan Ahn et al. (2002) yang mengkaji LAC dalam pelancongan. Metodologi ini dapat memberikan gambaran menyeluruh tentang kajian terdahulu serta pandangan dan definisi yang diutarakan oleh penyelik yang terlibat.

\section{Perbincangan}

\section{Faktor-faktor LAC dibangunkan}

Terdapat beberapa sebab proses LAC ini dibangunkan oleh Stankey et al., 1985. Pertama, pada tahun 1978 General Authorities Act (U.s. Public Law 96-625) menetapkan setiap Taman Negara membangunkan "kapasiti daya tampung pelawat" (visitor carrying capacities). Pada tahun 1979, peraturan bagi pelaksanaan Akta Pengurusan Hutan Negara (NFMA) menyatakan setiap hutan simpan negara perlu "memperuntukkan bagi menghadkan dan menerangkan kebolehgunaan pengunjung di kawasan tertentu sesuai dengan anggaran tahap maksimum penggunaan yang membolehkan proses semula jadi untuk beroperasi secara bebas serta tidak menjejaskan nilai-nilai yang sedia ada dalam kawasan hutan tersebut" (Federal Register, 1979 dalam Cole dan Stankey 1998). Disebabkan percubaan untuk mengembangkan lagi kapasiti daya tampung (Carrying Capacity) akan menyerap bahagian yang mempunyai sumber dalam pengurusan hutan, mereka juga khuatir kapasiti tersebut akan dibangunkan di kawasan yang tidak diperlukan (Washburne, 1982). Batasan konsep CC akan menjadi semakin jelas.

Selain itu, inspirasi dalam membangunkan LAC ini kerana kebimbangan bahawa penggunaan rekreasi ini semakin meluas, ini akan mengakibatkan peningkatan impak dan masalah pengurusan yang lain. Kebimbangan terhadap perubahan sifat semula jadi manusia yang berubah dalam rekreasi hutan dan dengan merasakan bahawa kurangnya perhatian terhadap perancangan pengurusan dan ia adalah satu cara yang tidak bagus bagi melindungi pelaburan yang telah dibuat rakyat Amerika terhadap hutan belantara melalui proses yang telah ditetapkan (Cole \& Stankey 1998). Cole dan Stankey (1998) merasakan kebimbangan terhadap masalah ini telah berkembang di bahagian hutan rimba yang telah tidak digunakan dan yang masih belum diusik. Keadaan ini menyebabkan mereka cuba mengasingkan kelemahan yang wujud dalam perancangan pengurusan hutan rimba sedia ada dan merangka satu proses yang boleh mengatasi sebanyak mungkin kelemahan yang wujud. Kajian yang telah dijalankan terhadap sistem sedia ada mendapati 
penyelesaiannya terlalu umum contohnya "mengekalkan keadaan alam sekitar' dan "menyediakan cara mengatasi" dan menjadi tidak berguna dalam situasi membezakan masalah, mengenal pasti strategi yang telah dijanjikan, atau menilai kejayaan pengurusan. Justeru, LAC menekankan spesifikasi dalam objektif dan dicapai serta perlu menggambarkan penamat melebihi daripada cara - keadaan melebihi daripada pengurusan tindakan.

\section{LAC dalam pelancongan}

Terdapat ramai pengkaji yang menulis perkongsian mereka menggunakan LAC dalam kajian pelancongan mereka terutamanya kawasan yang dilindungi. Ia adalah aplikasi awal untuk mengurus pengunjung di daratan bagi menandakan hutan di U.S (Stankey et al. 1984; McCoy et al., 1995). Terdapat sesetengah penulis melaporkan menggunakan LAC sebagai rangka kerja dalam pengurusan snorkeling di terumbu dan di taman marin (Roman et al., 2007; Schultz et al., 1999). Ahn et al., (2002) menggunakan LAC untuk memeriksa sikap penduduk memeriksa sikap penduduk untuk menentukan kesesuaian dan kegunaan zon pembangunan pelancongan di skala negara. McCool (1994) mencadangkan pengubahsuaian terhadap kerangka kerja LAC supaya diaplikasikan terus dalam pengurusan pelancongan serantau. Brunson (1998) mencadangkan penggunaan LAC dalam situasi di luar daripada hutan yang ditetapkan. Sementara itu, penggunaan LAC dalam pengurusan pengunjung dan rangka kerja pengurusan agak jarang berlaku di Eropah (Haider, 2006), Erkkonen dan Itkonen (2006) melaporkan penggunaan LAC di Taman Negara Finland. Kebanyakan aplikasi lepas berlaku di U.S namun konsep LAC menjadi asas kepada aplikasi di serata dunia (McCool, 2013).

Walaupun pelbagai jenis aplikasi yang dilaporkan dalam bahan bacaan yang melibatkan alam sekitar dan pelancongan, sama ada sebagai konsep atau perancangan kerangka kerja, penerimaan LAC dalam jurnal utama pelancongan amatlah sedikit (contohnya; Pengurusan Pelancongan, Sejarah Penyelidikan Pelancongan, Jurnal Penyelidikan Pengembaraan, Jurnal Pelancongan Lestari, Jurnal Ekopelancongan) (McCool, 2013). Tidak ramai juga pengarang memberikan perhatian terhadap LAC ini di dalam buku mengenai impak pelancongan kepada alam sekitar dan kebanyakannya masih menekankan bahawa "kapasiti daya tampung" (Carrying Capacity) sebagai penyelesaian kepada pelancongan ekologi dan kesan sosial. Walaupun dengan mengukuhkan kapasiti daya tampung namun masih lagi tetap akan ada perdebatan tentang kepentingan relatif dan kesukaran dalam membuat keputusan. LAC menekankan penggunanya supaya menilai secara jelas pilihan, nilai dan kepercayaan dalam membuat keputusan melebihi mereka yang berilusi tentang "objektif yang saintifik".

\section{Sembilan urutan dalam proses LAC (McCool 1996)}

Sistem ini akan berjaya dengan menjalankan kesemua langkah yang dinyatakan. Selain itu ia melibatkan input awam serta penglibatan mereka di setiap langkah. LAC ini bergerak dengan penerangan yang untuk preskripsi tertentu dan ia juga memerlukan ukuran persekitaran dan pemantauan keadaan.

Dalam kerangka konsep yang dibentangkan oleh Stankley et al. (1985), ia mengandungi 
sembilan turutan langkah yang telah ditetapkan (Aw, 2013). Kesemua sembilan langkah ini perlu dijalankan bagi memperoleh hasil yang terbaik. Berikut huraian setiap langkah dalam proses LAC.

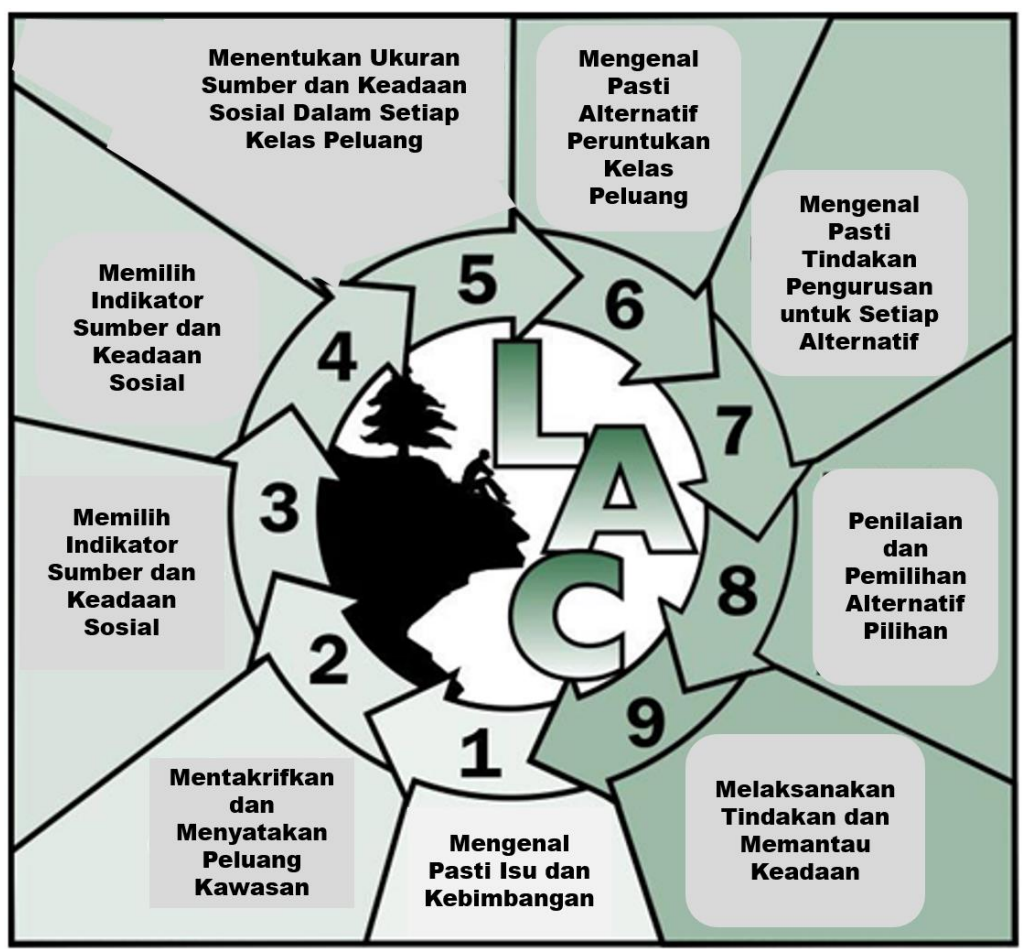

Sumber : Stankey et al. (1984)

Rajah 1 : Proses Had Perubahan Boleh Diterima

\section{Langkah 1 - Mengenal Pasti Isu dan Kebimbangan}

Tujuan langkah ini adalah untuk mengenal pasti isu-isu awam dan pengurusan kebimbangan yang berkaitan dengan ciri-ciri tersendiri dan ciri-ciri kawasan. Produk adalah penceritaan tentang nilai unik dan peluang yang perlu diketengahkan di kawasan tersebut dan masalah pengurusan yang perlu diberikan perhatian.

Rakyat tempatan dan pengurus bersemuka untuk mengenal pasti ciri-ciri istimewa atau kualiti kawasan yang perlu diberikan perhatian, masalah pengurusan atau dengan cara apakah untuk mengatasi kebimbangan tersebut, isu yang dirasakan penting oleh orang awam di kawasan pengurusan dan apakah peranan yang dimainkan oleh kawasan tersebut kepada negara dan serantau. Langkah ini menggalakkan pemahaman yang lebih baik terhadap sumber semula jadi di kawasan tersebut, konsep umum mengenai bagaimana sumber perlu diuruskan dan memfokuskan terhadap isu prinsip pengurusan.

\section{Langkah 2 - Mentakrifkan dan Menyatakan Peluang Kawasan}

Setiap kawasan contohnya hutan dan marin mempunyai kepelbagaian ciri-ciri fizikal dan biologi 
seperti batu karang, terumbu, air terjun, pantai, hutan dan dengan bukti penggunaan manusia. Ia mungkin melibatkan perbezaan ketara dari segi jumlah dan jenis pembangunan. Begitu juga, keadaan sosial seperti tahap dan jenis kegunaan dan jenis pengalaman rekreasi, berbeza dari satu tempat ke tempat lain. Jenis pengurusan yang diperlukan juga berbeza-beza di seluruh kawasan. Pengelasan peluang menerangkan bahagian atau zon sumber asli adalah berbeza dari segi sosial, sumber atau keadaan pengurusan yang dikekalkan. Sebagai contoh, penetapan terumbu karang yang lebih dalam memerlukan peralatan skuba manakala di kawasan cetek hanya memerlukan peralatan snorkeling sahaja.

\section{Langkah 3 - Memilih Indikator Sumber dan Keadaan Sosial}

Indikator merupakan elemen yang spesifik tentang sumber atau tatacara sosial terpilih bagi mewakili atau menunjukkan keadaan yang difikirkan sesuai dan boleh diterima di setiap peluang kelas. Petunjuk harus mudah untuk mengukur secara kuantitatif, berkaitan dengan syarat-syarat yang ditetapkan oleh kelas-kelas peluang dan mencerminkan perubahan dalam kegunaan rekreasi. Petunjuk adalah bahagian yang penting dalam rangka kerja LAC kerana kedudukannya mencerminkan keadaan keseluruhan didapati di kelas peluang. Ia adalah penting untuk memahami bahawa petunjuk individu tidak mungkin cukup menggambarkan keadaan tertentu kawasan. Ia adalah lambakan petunjuk yang digunakan untuk memantau keadaan. Disebabkan agak mustahil untuk mengukur keadaan dan perubahan setiap sumber atau ciri-ciri sosial dalam lingkungan sesebuah kawasan, beberapa indikator dipilih sebagai langkah keseluruhan semakan seperti semakan kesihatan keseluruhan. Kita selalu menjalankan ujian tekanan darah berbanding menjalankan ujian kimia darah yang lengkap.

\section{Langkah 4 - Sumber Inventori yang Sedia Ada dan Keadaan Sosial}

Inventori boleh menyebabkan pengambilan masa yang panjang dan merupakan komponen yang paling bernilai dalam perancangan. Dalam proses LAC, inventori adalah berpandukan kepada indikator di langkah ke 3. Sebagai contoh, tahap dan jenis pembangunan, kepadatan penggunaan dan impak oleh manusia terhadap mungkin boleh diukur. Angkubah yang lain seperti lokasi terumbu karang yang berbeza, kapal karam, dok kapal dan tempat tambatan juga boleh menjadi inventori dalam membangunkan pemahaman yang lebih baik terhadap kekangan dan peluang di sesebuah lokasi. Maklumat tentang inventori juga akan berguna di hari kemudian apabila menilai sesuatu alternatif. Inventori ini turut membantu pengurus menubuhkan piawaian realistik dan boleh dicapai. Dengan meletakkan inventori pada langkah yang keempat, perancang dapat mengelakkan mengumpul data yang tidak perlu.

\section{Langkah 5 - Menentukan Ukuran Sumber dan Keadaan Sosial Dalam Setiap Kelas Peluang}

Dalam langkah ini, mereka mengenal pasti julat keadaan bagi setiap indikator yang dianggap sesuai dan boleh diterima. Dengan mendefinisikan kesemua keadaan dalam kaedah pengiraan, penyediaan asas untuk menubuhkan kepelbagaian persekitaran serta tersendiri dalam kajian. Penyediaan ukuran ini ditakrifkan sebagai Had Perubahan yang Boleh Diterima "limits of acceptable change". Terdapat keadaan had maksimum yang dibenarkan dalam kelas peluang tertentu. Ia juga tidak semestinya objektif yang perlu dicapai. Pengumpulan data inventori di langkah 4 memainkan 
peranan penting dalam penetapan ukuran. Penyelidikan perlu menentukan julat keadaan yang diterima dalam setiap peluang kelas realistik dan boleh dicapai.

\section{Langkah 6 - Mengenal Pasti Alternatif Peruntukan Kelas Peluang}

Kebanyakan persekitaran marin berkemungkinan boleh diuruskan dengan beberapa cara. Taman marin sentiasa ketara perbezaan dari segi jumlah pembangunan, kepadatan manusia (termasuk penduduk dan pelancong) dan adanya peluang aktiviti rekreasi. Dengan menggunakan informasi daripada langkah 1 (isu dan kebimbangan di lokasi) dan langkah 4 (inventori keadaan sedia ada, pengurusan dan penduduk boleh mula untuk bersama-sama meneroka peluang yang ada di sesebuah lokasi serta menunjukkan perbezaan atau keunikan dan nilai tarikan di lokasi tersebut berbanding lokasi yang lain

\section{Langkah 7 - Mengenal Pasti Tindakan Pengurusan untuk Setiap Alternatif}

Peruntukan alternatif yang dicadangkan dalam angkah 6 hanya merupakan langkah pertama dalam proses bagi membangunkan alternatif yang lebih baik. Sebagai tambahan untuk memperoleh keadaan yang lebih baik dicapai, kedua-dua pihak iaitu pihak pengurusan dan masyarakat perlu mengetahui apakah tindakan pengurusan yang diperlukan untuk mencapai keadaan yang dikehendaki. Dari satu segi, langkah 7 memerlukan analisis kos yang ditakrifkan secara meluas yang akan dikenakan oleh setiap alternatif. Sebagai contoh, ramai orang mungkin tertarik dengan alternatif untuk melindungi sesuatu kawasan daripada pembangunan dan mengembalikan kepada keadaan asal tanpa wujud sebarang impak. Akan tetapi, alternatif ini mungkin memerlukan komitmen yang tinggi dari segi peruntukan untuk pengambilalihan dan penguatkuasaan bahawa alternatif tersebut mungkin tidak kelihatan menarik.

\section{Langkah 8 - Penilaian dan Pemilihan Alternatif Pilihan}

Dengan pelbagai kos dan faedah beberapa alternatif yang wujud, pihak pengurusan dan masyarakat boleh meneruskan peringkat penilaian, dan menjalankan urusan penguatkuasaan berdasarkan panduan dari orang ramai dan boleh memilih alternatif yang diutamakan. Penilaian perlu mengambil kira banyak faktor, termasuk tindak balas dari semua pihak terhadap isu yang dinyatakan di langkah 1 dan keperluan mengambil kira langkah pengurusan di langkah 7. Ia penting sebelum membuat penilaian dan pemilihan alternatif yang jelas dan tersedia untuk tatapan umum.

\section{Langkah 9 - Melaksanakan Tindakan dan Memantau Keadaan}

Dengan alternatif akhirnya dipilih dan dijadikan sebagai dasar oleh pembuat keputusan, tindakan pengurusan yang diperlukan (jika ada) dimasukkan ke dalam kesan dan program pemantauan dimulakan. Selalunya, pelan pelaksanaan, memperincikan tindakan, kos, jadual waktu dan tanggungjawab, akan diperlukan untuk memastikan pelaksanaan yang tepat pada masanya. Pemantauan program memberi tumpuan kepada penunjuk yang terpilih dalam langkah 3, dan membandingkan keadaan mereka dengan orang dikenal pasti dalam piawaian. Maklumat ini boleh digunakan untuk menilai kejayaan tindakan. Jika keadaan tidak bertambah baik, keamatan usaha pengurusan yang mungkin perlu ditambah atau tindakan baru yang dilaksanakan. 
Sekiranya kesemua langkah ini dapat dijalankan ia akan dapat menentukan jenis keadaan sumber, keadaan sosial yang boleh diterima serta boleh menetapkan tindakan untuk melindungi atau mencapai keadaan tersebut.

\section{Perubahan dalam pengurusan pelancongan (dari CC ke LAC)}

LAC ini direka untuk menjawab tentang kegagalan menggunakan pendekatan Carrying Capacity (CC) dalam menguruskan lawatan - kedua-dua kesan sosial dan alam sekitar di kawasan yang ditetapkan. Kegagalan pendekatan CC telah dijelaskan dengan baik di dalam literatur (McCool \& Lime, 2001; Buckley, 1999; Washburn, 1981; Wagr, 1974). Dalam semakan terhadap rangka kerja perancangan rekreasi, McCool et al. (2007) merumuskan :

Pengalaman dalam daya tampung rekreasi dalam menyelesaikan masalah yang rumit dan sering dikaitkan dengan rekreasi dan pembangunan pelancongan di kawasan biasanya berakhir dengan kegagalan. Bukan hanya daya tampung intrinsik tidak dapat dikenal pasti, tetapi polisi had penggunaan (sering digambarkan sebagai daya tampung) sering kali tidak berhasil dalam menyelesaikan masalah yang mendorong pencarian kapasiti. Kami keluarkan kesimpulan ini kerana tiga sebab:

1. Daya tampung adalah salah menyusun masalah kesan penggunaan

2. Fungsi teori untuk daya tampung rekreasi tidak sah

3. Pelaksanaan praktik daya tampung di kawasan liar adalah sukar

Pembaca yang merujuk kepada rujukan literatur ini akan membuat ulasan tambahan dan bab dalam buku yang ditulis oleh Coccossis (2004) sebagai penerangan berkaitan CC dalam perancangan dan pengurusan pelancongan.

LAC mewakili jika bukan sebagai paradigma baru dalam pengurusan, maka rangka semula pengurusan soalan yang menjurus terhadap pengurusan pengunjung alam semula jadi daripada "how many is too many" kepada "what are the acceptable conditions?"memfokuskan kepada mengenal pasti keadaan seperti yang diketengahkan oleh Coccossis (2004) dalam risalahnya yang menyokong penggunaan $\mathrm{CC}$ untuk pertambahan dan jangkaan perubahan negatif untuk peralihan nilai sosial. Seperti yang dinyatakan oleh Freimund (2001), perubahan dari CC kepada LAC adalah perubahan daripada memberi tumpuan kepada jumlah pengunjung kepada menekankan kualiti persekitaran.

\section{Kesimpulan}

Had yang boleh diterima atau LAC adalah salah satu konsep yang dikenali dalam perancangan kawasan yang dilindungi. Ia juga telah digunakan dalam pelbagai situasi dan direka sebagai tindak balas kegagalan kapasiti daya tampung (CC) berdasarkan pendekatan terhadap isu menyelesaikan konflik antara matlamat memelihara alam semula jadi dan membenarkan akses untuk lawatan atau pelancongan. LAC mempunyai tiga kekuatan yang perlu diberikan perhatian, iaitu (i) memfokuskan pengurusan terhadap mengenal pasti keadaan yang dikehendaki terlebih dahulu, kemudian mengenal pasti dan tindakan pengurusan yang berkesan; (ii) menekankan penghakiman nilai secara 
asas (intrinsik) terhadap perancangan pelancongan supaya dinyatakan dengan jelas dan oleh itu subjek akan dibincangkan dan (iii) penggunaan cara tradisional dalam menarik orang awam dalam pembangunan dan perlaksanaan.

LAC bukanlah dibangunkan untuk menyediakan rangka kerja negara atau global untuk polisi pelancongan dan tidak pernah bertujuan seperti itu. LAC tidak menyediakan jawapan seperti nilai adalah keutamaan dalam penyediaan sesebuah struktur untuk perancang, pengurus dan kawasan kajian utuk bekerja dengan kerumitan bagi mengintegrasikan pemeliharaan dan mencapai matlamat. Sementara ia telah digunakan di kawasan persekitan yang dilindungi, penggunaannya sebagai alat perancangan peringkat serantau untuk pembangunan pelancongan telah terhad. Penggunaan ini perlu diuji, jadi kita boleh belajar lebih lagi mengenai keupayaannya.

\section{Rujukan}

Ahn, B.Y., B.K. Lee, \& C.S Shafer. (2002). Operationalizing sustainaility in regional tourism planning; an application of the limits of acceptable change framework. Tourism Management 23(1); 1-15

Aw, S.L. (2013). Establishing limits of acceptable change ( LAC ) for anthropogenic development on Mabul Island, Sabah, Malaysia., pp.411-417.

Buckley, R. (1999). An ecological perspective on carrying capacity. Annals of Tourism Research 26 (3), 705-708.

Brunson, M. W. (1998). Beyond wilderness: Broadening the applicability of limits of acceptable change. ? In: McCool, S.F.; Cole, D.N., comps. Proceedings - limits of acceptable change and related planning pro- cesses: progress and future directions. Gen. Tech. Rep. INT-GTR-371. Ogden, UT: U.S.

Corbin, J. \& Strauss, A. (2008). Basics of qualitative research: Techniques and procedures for developing grounded theory (3rd ed.). Thousand Oaks, CA: Sage.

Cocossis, H. \& A. Mexa. (2004). The challenge of tourism carrying capacity assessment; theory and practice. Ashgate Publ. 294 p.

Cole, D. \& McCool, S. (1997). Limits of acceptable change and related planning processes: a workshop. United States Department of Agriculture, Forest Service, pp.1-2. Available at: http://www.leopold .wilderness.net/pubs/313.pdf.

Cole, D.N. \& Stankey, G. (1998). Historical development of Limits of Acceptable Change: conceptual clarifications and possible extensions. United States Department of ..., pp.5-9. Available at: http://www.fs.fed.us/rm/pubs_int/int_gtr371/int_gtr371_005_009.pdf.

Denzin, N. K. (1970). The research act: A theoretical introduction to sociological methods. New York: Aldine.

Erkkonen, J. \& P. J. Itkonen. (2006). Monitoring sustainable nature tourism in practice experiences from Pyha-Luosta National Park, Finland in Siegrist, D., Clivaz, C., Hunziker, M. \& Iten, S. (eds.) (2006). Exploring the Nature of Management. Proceedings of the Third International Conference on Monitoring and Management of Visitor Flows in Recreational and Protected Areas. University of Applied Sciences Rapperswil, Switzerland, 13-17 September 2006.

Freimund, W.A. \& D.N. Cole. (2001). Use Density, Visitor Experience, and Limiting Recreational Use in Wilderness: Progress to Date and Research Needs In: Freimund, Wayne A.; Cole, David 
N., comps. 2001. Visitor use density and wilderness experience: proceedings; 2000 June 1-3; Missoula, MT. Proc. RMRS-P-20. Ogden, UT: U.S. Department of Agriculture, Forest Service, Rocky Mountain Research Station.

Frisell, Sidney S., Jr. (1963). Recreation Use of Campsite in the Quentico-Superior Canoe Country. St. Paul, MN; University of Minnesota. 66p. Thesis.

Haider, W. (2006). North American idols: Personal observations on visitor management frameworks and recreation research in Siegrist, D., Clivaz, C., Hunziker, M. \& Iten, S. (eds.) (2006). Exploring the Nature of Management. Proceedings of the Third International Conference on Monitoring and Management of Visitor Flows in Recreational and Protected Areas. University of Applied Sciences Rapperswil, Switzerland, 13-17 September 2006. Rapperswil.

Marsh H (1995) The Limits of Detectable Change. In Grigg GC, Hale, PT, Lunney D (Eds.). Conservation through Sustainable Use of Wildlife. Centre for Conservation Biology. Brisbane, Australia: The University of Queensland, pp. 122-130

McCool, S.F. (2013). Limits of acceptable change and tourism. Routledge Handbook of Tourism and the Environment, pp. 285-298.

McCool, S.F. \& Lime, D.W. (2001). Tourism carrying capacity: Tempting fantasy or useful reality? Journal of Sustainable Tourism. 9(5): 372-388.

McCool, S. F. (1996). Limits of Acceptable Change: A Framework for Managing National Protected Areas: Experiences from the United States. Workshop on Impact Management in Marine Parks, p.15pp.

McCool, S. F. (1994). Planning for sustainable nature dependent tourism development: The limits of acceptable change system. Tourism Recreation Research 19(2): 51-55

Mccoy, L., Krumpe, E. E. \& Allen, S. (1995). Limits of Acceptable Change Planning - evaluating implementation by the US Forest Service. International Journal of Wildrnesss. 1(2); 18-22

Oliver, J. (1995). Is the "Limits of Acceptable Change" concept useful for environmental managers? A case study from the Great Barrier Reef Marine Park. In: Griff, G. C., Hale, P. T. \& Lunney, D. (Eds.). Conservation Through Sustainable Use of Wildlife. Centre for Conservation Biology. University of Queensland. pp 131-139

Roggenbuck JW, Williams DR, Watson AE (1993) Defining Acceptable Conditions in Wilderness. Environ Mgt 17 (2): 187-197

Roman, G.S.J., P. Dearden \& R. Rollins. (2007). Application of zoning and "limits of acceptable change to manage snorkeling tourism. Environmental Management 39:819-830.

Schultz, E., S.F. McCool \& D. Kooistra. (1999). Management plan, Saba Marine Park. Saba Conservation Foundation, The Bottom, Saba Netherlands Antilles. $46 \mathrm{p}$

Tourism Malaysia. 2015. Laporan tahunan. Kementerian Pelancongan Malaysia. Putrajaya, Malaysia

Stankey, G., McCool, S. \& Stokes, G. (1984). Limits of acceptable change: a new framework for managing the Bob Marshall Wilderness complex. Western Wildlands, 3(10), pp.33-37. Available at: http://prdp2fs.ess.usda.gov/Internet/FSE_DOCUMENTS/stelprdb5346576.pdf.

Stankey G. H., Cole, D. N., Lucas, R. C., Petersen, M. E. \& Frissell, S.S. (1985).( The Limits of Acceptable Change (LAC) System for Wilderness Planning. Department of Agriculture, U.S

Wagar, J.A. (1974). Recreational carrying ca- pacity reconsidered. Journal of Forestry. 72(5): 274 278.

Washburne, R.F. (1982). Wilderness recreation carrying capacity: Are numbers necessary? Journal of Forestry. 80: 726-728. 